\title{
PKM PENDAMPINGAN KELUARGA DAN KADER TERHADAP PENDERITA KUSTA DALAM MENCEGAH KECACATAN DI KELURAHAN LIMO KOTA DEPOK JAWA BARAT
}

\author{
Tatiana Siregar ${ }^{1)}$, Diah Ratnawati ${ }^{2)}$ \\ 1), 2) Fakultas Ilmu Kesehatan \\ Universitas Pembangunan Nasional "Veteran" Jakarta \\ E-mail: tatiana_siregar@yahoo.co.id ${ }^{1)}$, ratnawati.diah@yahoo.co.id ${ }^{2)}$
}

\begin{abstract}
ABSTRAK
Kusta adalah penyakit menular yang disebabkan oleh mycobacterium leprae. Penyakit kusta belum lenyap dari masyarakat Indonesia, dikarenakan ketidaktahuan dan rendahnya pengetahuan masyarakat dalam mendeteksi, mencegah luka kusta yang berisiko terjadi kecacatan dan stigma dari masyarakat. Stigma pada penderita kusta juga masih terjadi di wilayah Kerja Puskesmas Kelurahan Limo Kota Depok. Maka dari itu dukungan dan pendampingan Kader kesehatan dan keluarga dalam promotif dan preventif penyakit kusta sangat penting dilakukan berupa kegiatan Program Kemitraan Masyarakat (PKM). Mitra PKM yaitu para Kader Kesehatan di Kelurahan Limo Kota Depok, yang bertujuan untuk mengoptimalkan peran Kader agar dampat membantu mengurangi kecacatan pada penderita kusta. Keterlibatan Kader, Orang Yang Pernah Menderita Kusta (OYPMK) serta keluarganya yang berjumlah 42 orang telah diberikan penyuluhan Pengetahuan tentang penyakit Kusta, serta cara melakukan Perawatan Luka. Hasil pengabdian masyarakat yang dilakukan pada tanggal 30 sampai dengan 31 Juli 2019 secara kontiniu, serta setiap tahapan kegiatan dinilai dengan kuesioner berisi pengetahuan penyakit Kusta dan cara merawat luka, dimana didapatkan peningkatan nilai pre intervention dengan mean 60,46 dan post intervention menjadi mean 85,11. Kesimpulan dari PKM ini, Kader dan keluarga OYPMK perlu pemantauan dan bimbingan dalam merawat penderita kusta secara berkala bekerja sama dengan Pemerintah Kota Depok.
\end{abstract}

Kata kunci: Luka; Penderita kusta; OYPMK.

\section{PENDAHULUAN}

Kusta adalah penyakit menular yang disebabkan oleh mycobacterium leprae yang mempengaruhi kulit dan saraf perifer serta menyebabkan kerusakan fungsi saraf dan tidak dapat diperbaiki hingga mengakibatkan ketidakmampuan kronis (Zhang et al., 2009) Kusta adalah penyakit menular menahun dan disebabkan oleh kuman kusta (mycobacterium leprae) yang menyerang saraf tepi, kulit dan jaringan tubuh lainnya (Bujawati \& Alam, 2016).

Penyakit kusta di wilayah Kelurahan Limo sebagai bagian dari wilayah Kota Depok, tahun 2016 ditemukan ada 40 penderita kusta Baru dengan wilayah Puskesmas Limo sebanyak 16 penderita, Puskesmas Cipayung terdapat 14 penderita, dan Puskesmas Bojongsari sebanyak 10 penderita (Depok Pos, 2017). Berdasarkan informasi di atas untuk penderita MB yang selesai berobat baru $66,51 \%$ dan tipe PB 92,86\%, hal ini perlu peran petugas kesehatan untuk memotivasi penderita kusta tetap mengontrol status kesehatannya secara berkala untuk pengobatan Multi Drug Theraphy $(M D T)$ sesuai jadwal yang di buat, agar penderita kusta tidak menglami kecacatan lebih lanjut. Karena pengobatan yang lama ini menuntut penderita kusta untuk patuh dalam pengobatan, seperti penelitian dari Fatmala (2016) menyampaikan ada faktor yang berhubungan dengan kepatuhan minum obat pada penderita kusta yaitu pengetahuan, dukungan keluarga, stigma masyarakat, peran petugas dan ketersediaan obat. Penyuluhan yang efektif akan memberikan motivasi kepada penderita untuk patuh minum obat.

Kepatuhan penderita kusta dalam konsumsi MDT ini sangat ditentukan oleh faktor perilaku sehat terutama dari sisi pengetahuan sebagai faktor dominan dalam patuhnya penderita kusta dalam konsumsi MDT (Siregar, T; dan Ratnawati, 2018). Patuhnya Pengobatan kusta sangat 
memerlukan peran keluarga dalam memberikan motivasi dan pengawasan kepada penderita untuk minum obat secara teratur. Hal ini disebabkan karena proses pengobatan kusta adalah 2 tahun dan masa pengawasan sampai dengan 5 tahun. Panjangnya proses pengobatan kusta inilah yang seringkali mendorong pasien untuk tidak patuh minum obat kusta (Tilis, Mayasari, Suprapto, Surya, \& Husada, 2012). Bila penderita kusta tidak meminum obat secara tertib maka kuman kusta dapat menjadi aktif kembali dan dapat menimbulkan gejala-gejala baru yang akan memperburuk keadaan penderita menjadi cacat (Kemenkes RI, 2014)

Ditegaskan juga oleh Indanah (2003) dukungan keluarga dapat mencegah dan menurunkan kecacatan, kondisi fisik penderita kusta yang mengalami perubahan akibat kecacatan kusta berdampak dalam kehidupan penderita, penderita akan menghadapi bentuk stigma. Efka, Wibriani, \& Kristiana (2017) menyampaikan dampak sosial yang dialami penderita kusta dan seringkali menjadi sumber permasalahan dalam kehidupannya yaitu kecacatan pada tubuh penderita yang membuat sebagian besar masyarakat merasa jijik dan umumnya akan menyebabkan penderitanya dijauhi, dikucilkan oleh masyarakat, dan sulit mendapatkan pekerjaan

Stigma pada penderita kusta juga masih terjadi di wilayah Kerja Puskesmas Keluarahan Limo Kota Depok, dan menurut Guffman (1963) dalam (Siregar \& Ratnawati, 2018) menjelaskan pengertian "stigma" sebagai atribut yang sangat mendiskreditkan individu, stigma adalah orang yang tidak diterima dan tidak diberikan rasa hormat dan menganggap teman-temannya, yang didiskualifikasi dari penerimaan sosial penuh. Hal ini terkait dengan 1) cacat fisik; 2) noda (karakter, seperti berhubungan dengan alkoholisme dan obat), dan 3) ras, bangsa, kelas sosial, seksualitas dan agama yang dianggap sebagai kelas dua oleh kelompok lain.

Survei pendahuluan Tim Abdimas telah melakukan wawancara dengan Dinas Kesehatan Kota Depok tanggal 2 Februari 2019 didapatkan informasi dengan Dinas Kesehatan Kota Depok tanggal 5 Februari 2019 terkait kesehatan penderita kusta dan belum berjalannya program bagi penderita kusta dan keluarganya serta Orang Yang Pernah Mengalami Kusta (OYPMK) dalam mengatasi stigma bagi penderita kusta dan keluarganya, sehingga stigma yang ada di diri penderita kusta dan keluarganya menjadi hambatan bagi penderita untuk mendapatkan lapangan pekerjaan di lingkungan sekitarnya, dan secara tidak langsunpun menggangu pemenuhan kebutuhan ekonominya. Namun, program pemberdayaan penderita kusta di Puskesmas Kelurahan Limo selama ini masih dalam tahap wacana maka perlu dibentuk Kelompok di masyarakat. Kelompokkelompok ini diharapkan nantinya dapat melakukan kegiatan yang dapat meningkatkan status kesehatan penderita kusta. Maka Tim Abdimas tertarik untuk melakukan kegiatan pemberdayaan masyarakat pada kelompok penderita kusta mulai dari Kader Kesehatan, OYPMK, dan keluarganya dalam bentuk Program Kemitraan Masyarakat (PKM). PKM ini dilakukan di wilayah kerja Puskesmas Kelurahan Limo Kota Depok. PKM yang dilakukan berupa pelatihan keterampilan dalam merawat luka dan pengawasan pemberian Multi Drug Theraphy (MDT). Tim Abdimas dalam kegiatan PKM ini bertindak sebagai fasilitator kepada kelompok ini.

Banyaknya permasalahan yang dialami penderita kusta, OYPMK dan keluarganya dalam kehidupan sehari-hari di lingkungan sekitar tinggal mereka. Permasalahan dari kondisi penderita kusta seperti yang sudah dijelaskan di atas terdapat rusaknya jaringan tubuh atau kecacatan yang terjadi membuat penderita kusta secara tidak langsung disingkirkan oleh masyarakat, sehingga mereka mendapat Stigma. Penolakan dapat dirasakan langsung maupun tidak langsung akan berakibat masalah psikologis, ketimpangan sosial, ekonomi bahkan tidak adanya kesempatan mereka untuk mendapatkan pekerjaan di tempat lain. Akhir dari semua penolakan ini yang sangat dirasakan dampaknya adalah pemenuhan kebutuhan ekonomi rumah tangga mereka. Kondisi ini 
bagi Kader Kesehatan, OYPMK, dan keluarganya dalam peningkatan status kesehatan penderita kusta. Maka Tim Abdimas memberikan solusi dalam permasalahan ini dengan memberikan keterampilan dan pengalaman kepada Kader Kesehatan, OYPMK dan keluarganya untuk menjadi pendamping penderita kusta selama proses pengobatan kusta.

\section{METODE PELAKSANAAN}

\section{Tempat dan Waktu.}

Kegiatan PKM Pendampingan Keluarga dan Kader Kesehatan untuk Penderita Kusta di RW 02 Krukut Kelurahan Limo. Lokasi dipilih termasuk daerah binaan Puskesmas Kelurahan Limo, dan terdapat dua orang penderita Kusta, serta kurang fahamnya penderita kusta dan keluarga serta warga sekitar mengenai penyakit kusta dan cara perawatan pada luka yang ada pada penderita kusta (Siregar \& Ratnawati, 2018). Maka perlu dibentuk kelompok pendamping untuk penderita kusta didalam meningkatkan pengetahuannya dan keterampilan dalam pencegahan kecacatan akibat kusta.

\section{Khalayak Sasaran.}

Kegiatan PKM dihadiri oleh 42 orang yang terdiri dari Kader Kesehatan dan warga setempat.

\section{Metode Pengabdian.}

Metode pelaksanaan kegiatan PKM ini berisi sosialisasi, penyuluhan, dan pelatihan kepada peserta sebagai pendamping penderita kusta tentang upaya pencegahan kecacatan pada penderita kusta. Pengabdin masyarakat diselenggarakan dengan melalui kemitraan dengan Kelurahan Limo, dan Kader-Kader Kesehatan di Kelurahan Limo. Kegiatan PKM dapat terlaksana setelah mendapat izin dari Dinkes (Nomor 070/3375-Umum, tertanggal 16 Juni 2019) dan KesBangPol Kota Depok (Nomor 071/818-Kesbangpol, tertanggal 13 Juni 2019) serta Puskesmas Kelurahan Limo. Setelah izin keluar Tim Abdimas melakukan survey wilayah yang tempat dilaksanakan kegiatan, dan melakukan kontrak waktu dengan kelompok Kader Kesehatan serta Pak RW 02 setempat, dan kesepakatan didapat pelaksanaan kegiatan hanya dapat dilakukan satu hari penuh.

Kegiatan PKM dimulai dengan persiapan materi penyuluhan untuk peserta berisi pemahaman tentang penyakit kusta: mulai dari pengertian penyakit kutsa, penyebab penyakit kusta, tanda dan gejala penyakit kusta, penularan penyakit kusta, hal-hal yang perlu diwaspadai dan dihindari oleh penderita kusta, pengobatan penyakit kusta, dan cara perawatan luka akibat kusta. Tahap awal kegiatan, mitra diharapkan dapat menjadi informan yang baik untuk penderita kusta dan keluarganya serta warga sekitar penderita kusta. Pada Tahap pelaksanaan berupa kegiatan penyuluhan dan pelatihan keterampilan merawat luka, maka mitra diharapkan peserta dapat menjadi sebagai pentrasfer informasi mengenai penyakit kusta serta keterampilan dalam merawat luka dari pengusul abdimas. Tahap akhir, mitra diharapkan sudah mampu secara mandiri menjadi pendamping penderita kusta dalam pencegahan kecacatan akibat penyakit kusta.

\section{Indikator Pencapaian.}

Kegiatan PKM ini bertujuan untuk meningkatkan kemampuan pendamping penderita kusta (kader kesehatan, keluarga penderita kusta, dan OYPMK) dalam mencegah kecacatan akibat penyakit kusta. Tujuan khusus kegiatan ini adalah terlaksananya kegiatan transfer pengetahuan dan transfer keterampilan dari Tim Pelaksana Abidmas sebagai nara sumber dalam rangka mendukung program pemerintah untuk mencegah kecacatan pada penderita kusta. Hasil PKM ini dapat terpublikasi dalam bentuk Modul bagi Kader Kesehatan serta dapat dibaca oleh halayak luas pada Jurnal Penelitian atau Abdimas yang berstandar Nasional. 


\section{Evaluasi Kegiatan.}

Evaluasi kegiatan dilakukan pada kelompok pendamping penderita kusta dan persentase peserta yang terlibat dalam kegiatan ini, serta ada atau tidaknya kesepatan pihak Puskesmas Kelurahan Limo untuk upaya pemberdayaan Kader Kesehatan secara berkelanjutan dalam upaya pencegahan kecacatan akibat penyakit kusta. Pelaksananaan dimulai dengan memasang spanduk dan menyampaikan undangan kepada kader kesehatan dan masyarakat untuk hadir pada kegiatan PKM ini. Tim Abdimas mengukur pemahaman peserta dengan memberikan kuesioner 15 butir pertanyaan sekitar penyakit kusta dan perawatannya. Kuesioner diberikan sebelum dilakukan kegiatan penyuluhan dan demonstrasi cara merawat luka, dan kuesioner diberikan kembali setelah dilakukan kegiatan. Sedangkan keterampilan peserta Tim Abdimas nilai secara observasi. Pengukuran dinilai dengan analisa univariat dan bivariat perbandingan pemahaman peserta sebelum dan sesudah dilakukan penyuluhan tentang penyakit kusta dan demonstrasi perawatan luka. Keberlangsungan kelompok pendamping penderita kusta dilakukan dengan bantuan pembinaan dari Puskesmas wilayah kerja Limo Kota Depok.

\section{Kerja Sama Lintas Sektoral.}

Kerja sama lintas sektoral berbentuk kemitraan dengan Kader Kesehatan Kelurahan Limo sebagai tempat PKM dan mitra aktif pada setiap tahan PKM kelompok Pendamping penderita Kusta

\section{HASIL dan PEMBAHASAN}

Kegiatan PKM Pendampingan Penderita Kusta di Kelurahan Limo dilakukan pada hari Rabu, tanggal 31 Juli 2019. Gambar 1 menunjukkan tim abdimas dibantu oleh dua orang mahasiswa Keperawatan FIKES UPNVJ sebagai fasilitator. Gambar 2, menunjukkan periode penyuluhan tentang penyakit kusta dan perawatannya.

Tim Abdimas dalam pelaksanaan PKM ini juga mempersiapkan Buku Modul dengan judul "Ayo Cegah Kecacaatan Pada Kusta" yang berisi tentang materi pengetahuan tentang penyakit kusta serta teknik melakukan perawatan luka. Saat pelaksanaan kegiatan PKM pengabdi membagi tim sebagai berikut:

a. Penyuluh untuk materi penyakit kusta disampiakan oleh Ns. Diah Ratnawati, M.Kep., Sp.Kep. Kom

b. Praktek dan demonstrasi teknik merawat luka dilakukan oleh tim abdimas Ns. Tatianan Siregar, M.Kep., MM.

c. Tim abdimas juga dibantu oleh dua mahasiswa sebagai fasilitator pada kegiatan PKM ini.

d. Pelaksanaan ajakan mencegah kecacatan pada kusta dengan dibagikannya Lefalet dilingkungan sekitar.

Hambatan yang dialami perlunya pelatihan lebih intens kepada peserta untuk berlatih melakukan komunikasi sebagai pemberi pendidikan kesehatan kepada keluarga dan masyarakat. Hasil data PKM didapatkan $100 \%$ peserta (42 orang) adalah perempuan dengan varian umur seperti pada Tabel 1.

Tabel 1. Distribusi Umur Peserta PKM Pendampingan Penderita Kusta Di Kelurahan Limo Kota Depok, Tahun $2109(\mathrm{n}=42)$

\begin{tabular}{lccc}
\hline Variabel & Mean & SD & Minimum - Maksimum \\
\hline Umur & 37,36 & 5,82 & $37-50$ \\
\hline
\end{tabular}




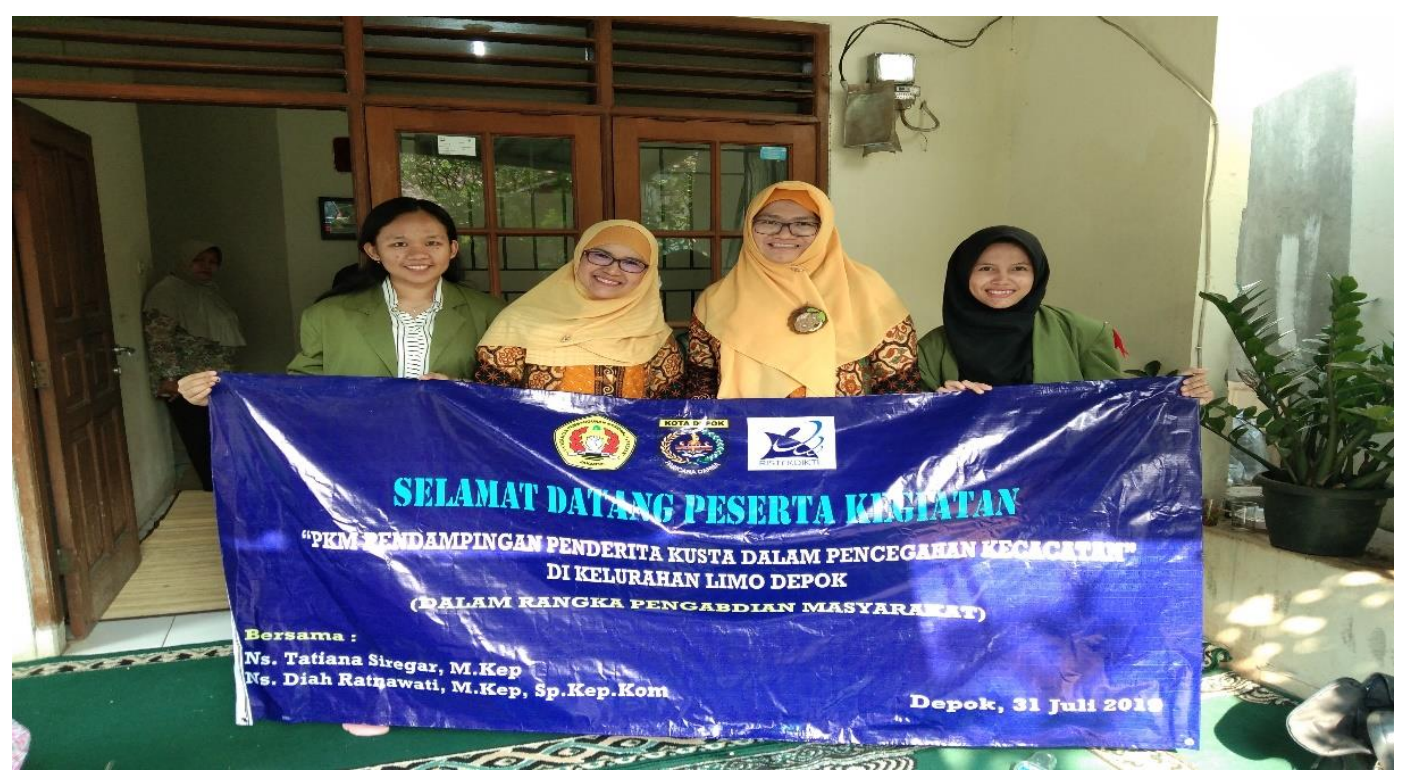

Gambar 1. Tim Abdimas Dibantu Oleh Dua Orang Mahasiswa Keperawatan FIKES UPNVJ Sebagai Fasilitator

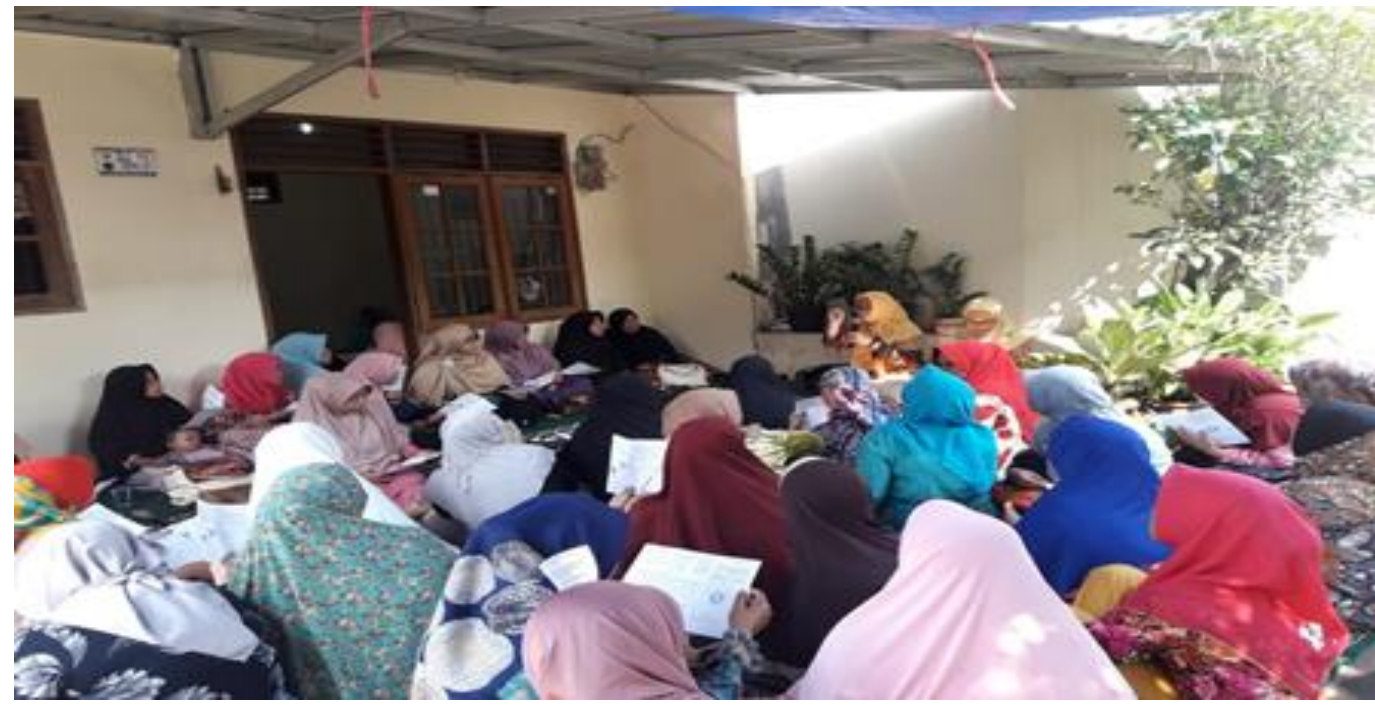

Gambar 2. Periode Penyuluhan Tentang Penyakit Kusta dan Perawatannya

Berdasarkan Tabel 1, rata-rata usia peserta 37,36 tahun. Semua peserta berada pada usia produktif. Ibu-ibu kader kesehatan dan peserta lainnya mempunyai semangat yang positif untuk mengikuti kegiatan PKM ini. Hasil PKM didapatkan pengetahuan peserta dijabarkan pada Tabel 2.

Tabel 2. Pengetahuan Peserta PKM Pendampingan Keluarga Di Kelurahan Limo Kota Depok Tahun $2019(\mathrm{n}=42)$

\begin{tabular}{|c|c|c|c|c|c|}
\hline \multirow[b]{2}{*}{ Variabel } & \multicolumn{2}{|c|}{ Sebelum Penyuluhan } & \multicolumn{2}{|c|}{ Sesudah penyuluhan } & \multirow[t]{2}{*}{$p$ value } \\
\hline & Mean & SD & Mean & $S D$ & \\
\hline Pengetahuan & 60,46 & 7,4 & 35,11 & 4,85 & 0,000 \\
\hline
\end{tabular}


Tabel 2, dijelaskan bahwa pengetahuan peserta sebelum diberi penyuluhan rata-rata 60,46, dan setelah diberi penyuluhan dan demonstrasi praktik cara merawat luka pada penderita kusta ratarata 85,11 . Maka disimpulkan ada pengaruh yang signifikan perubahan pengetahuan peserta setelah mendapat paparan pengetahuan tentang penyakit kusta dan cara melakukan perawatan luka, dengan $p$ value $=0,000$

Selain menilai pengetahuan peserta tim abdimas juga menilai kemampuan psikomotor peserta dengan melakukan observasi keterampilan cara merawat luka, dengan menggunakan lima point yang diobservasi: 1) Cuci tangan sebelum tindakan, 2) Persiapan alat, 3) Melakukan teknik perawatan luka sesuai langkah-langkah panduan, 4) Mempertahankan kesterilan dan kebersihan alat-alat yang digunakan, 5) Cuci tangan sesudah tindakan. Selain itu juga dilakukan demonstrasi cara melakukan perawatan luka kusta, seperti pada Gambar 3.

Gambar 4 menunjukkan foto bersama sebagian peserta kegiatan pkm pendampingan keluarga dan kader kesehatan di kelurahan limo tahun 2019.

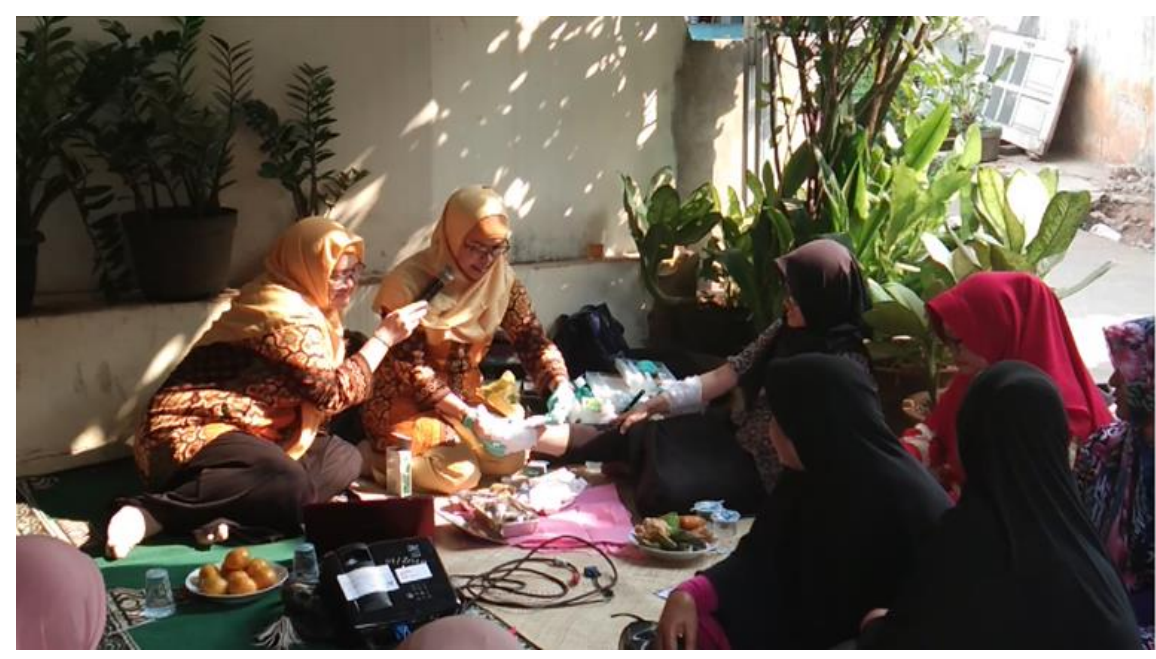

Gambar 3. Demonstrasi Cara Melakukan Perawatan Luka Kusta

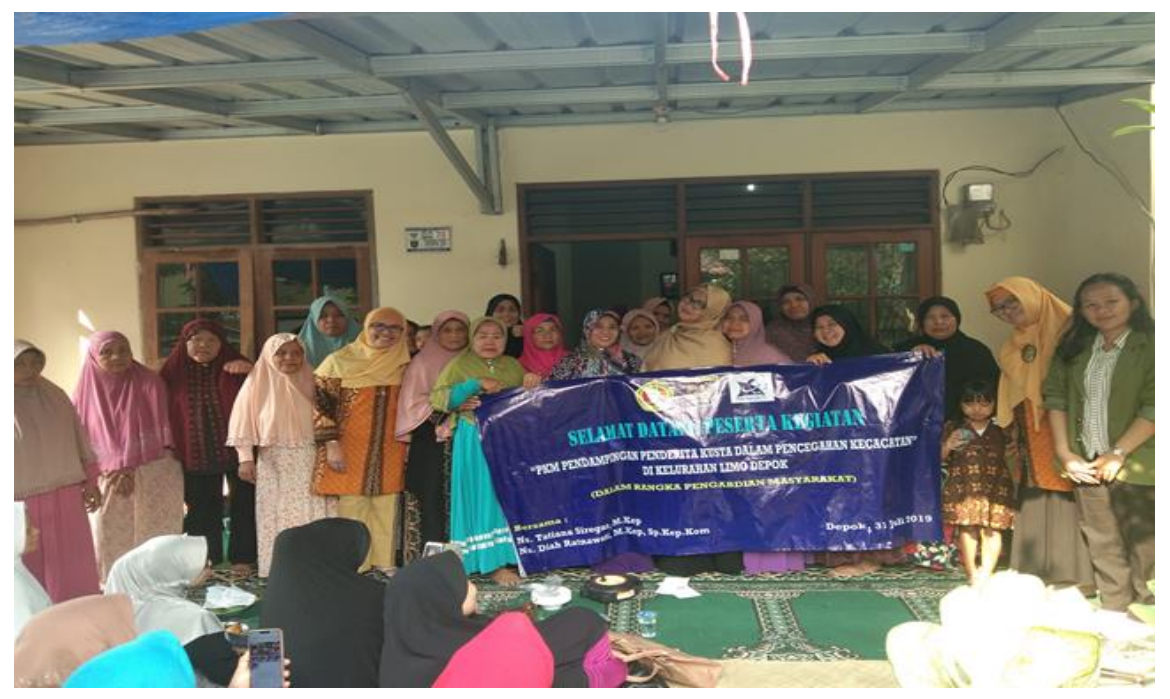

Gambar 4. Bersama Sebagian Peserta Kegiatan PKM Pendampingan

Keluarga dan Kader Kesehatan di Kelurahan Limo Tahun 2019 
Tabel 3. Keterampilan Peserta PKM Pendampingan Keluarga Di Kelurahan Limo Kota Depok Tahun $2019(\mathrm{n}=42)$

\begin{tabular}{cccccc}
\hline & \multicolumn{2}{c}{ Sebelum Penyuluhan } & \multicolumn{2}{c}{ Sesudah penyuluhan } & \multirow{2}{*}{ p value } \\
\cline { 2 - 5 } Variabel & Mean & SD & Mean & SD & \\
\hline Cara merawat luka & 2,43 & 0.501 & 4,57 & 0,497 & 0,000 \\
\hline
\end{tabular}

Berdasarkan pengamatan keterampilan peserta didapat hasil seperti pada Tabel 3. Berdasarkan Tabel 3, ada perubahan yang signifikan keterampilan peserta antara sebelum dan sesudah diberikan demonstrasi cara merawat luka denga $p$ value $=0,000$. Ketrampilan sebelum dilakukan demonstrasi rata-rata 2,43, sedangkan sesudah demonstrasi keteramilan peserta rata-rata 4,57.

Kegiatan PKM ini sangat dirasakan manfaatnya oleh peserta, sehingga semua peserta mempunyai sikap untuk bersedia mendukung program Puskesmas dan Pemerintah dalam mencegah kecacatan pada Kusta.

\section{KESIMPULAN}

Kegiatan PKM Pendampingan Keluarga dan Kader Kesehatan untuk penderita kusta sampai tahap evaluasi menunjukkan perubahan pengetahuan dan keterampilan yang signifikan setelah dipaparkan mengenai penyakit kusta dan cara perawatannya, khususnya luka pada kusta yang berisiko terjadinya kecacatan.

\section{Ucapan Terima Kasih}

Tim abdimas mengucapakan terima kasih kepada seluruh Kader Kesehatan dan Keluaraga penderita kusta serta OYPMK yang telah berpartisipasi dalam kegiatan ini serta Puskesmas Wilayah kerja Kelurahan Limo dan Kelurahan Limo yang telah memberi izin dan memfasilitasi proses kegiatan PKM ini.

\section{REFERENSI}

Bujawati, E., \& Alam, A. S. (2016). Gambaran Persepsi Pasien Tentang Penyakit Kusta dan Dukungan Keluarga Pada Pasien Kusta di RS . Dr . Tadjuddin Chalid Makassar Tahun 2015. 8, 29-38.

Depok Pos. Waspada Penularan Penyakit Kusta di Depok, 25 Januari 2017. , (2017).

Efka, G., Wibriani, P., \& Kristiana, I. F. (2017). BERI AKU KESEMPATAN Studi Fenomenologis Pengalaman Penyesuaian Diri pada Penderita Kusta setelah Kembali ke Lingkungan Masyarakat. 6(1), 181-185.

Fatmala, K. A. (2016). Analisis faktor yang berhubungan dengan kepatuhan minum obat kusta di Kecamatan Pragaan. Jurnal Berkala Epidemiologi, 4(1), 13-24.

https://doi.org/10.20473/jbe.v4i1.13-24

Indanah. (2003). Dukungan Keluarga Berhubungan dengan Kecacatan Penderita Kusta.

Kemenkes RI. (2014). Buku Saku Pengendalian Kusta. Jakarta.

Siregar, T., \& Ratnawati, D. (2018). Pengalaman Keluarga Merawat Penderita Kusta dalam Menghadapi Stigma Masyarakat di Kelurahan Limo Depok - Jawa Barat. 1(2), 65-84. 
Siregat, T; dan Ratnawati, D. (2018). Faktor-Faktor Perilaku Sehata Penderita Kusta Terhadap Kepatuhan Konsumsi MDT di Wilayah Kerja Puskesam Depok Jawa Barat. Jakarta: Proses Reiview Jurnal Care.

Tilis, M. W. I., Mayasari, E., Suprapto, S. I., Surya, S., \& Husada, M. (2012). Hubungan motivasi keluarga dengan tingkat kepatuhan minum obat pada penderita kusta. 11-16.

Zhang, F. R., Huang, W., Chen, S. M., Sun, L. D., Liu, H., Li, Y., ... Liu, J. J. (2009). Genomewide association study of leprosy. The New England Journal of Medicine, 361(27), 2609-2618. https://doi.org/NEJMoa0903753 [pii]\r10.1056/NEJMoa0903753 